\title{
Short-term mortality in post-emergent larval capelin Mallotus villosus. I. Analysis of multiple in situ estimates*
}

\author{
C. T. Taggart ${ }^{1, * *}$, W. C. Leggett ${ }^{2}$ \\ ${ }^{1}$ Department of Biology, Dalhousie University, Halifax, Nova Scotia B3H 4J1, Canada \\ ${ }^{2}$ Department of Biology, McGill University, 1205 Avenue Docteur Penfield, Montreal, Québec H3A 1B1, Canada
}

\begin{abstract}
Forty short-term mortality estimates of post-emergent larval capelin Mallotus villosus in a small embayment in eastern Newfoundland during 1981 to 1983 ranged from 3 to $100 \% \mathrm{~d}^{-1}$, and averaged $60 \% \mathrm{~d}^{-1}$ Mortality estimates derived under 5 sets of different assumptions regarding immigration and emigration showed that failure to account for variation in immigration rates (production of newly-emerged larvae) greatly biased the mortality estimates. Larval immigration alone explained between 32 and $66 \%$ of the apparent mortality. The contagious distribution of pre-emergent larvae was a major contributor to imprecise estimates of immigration. The effect of advective transport on population dispersion was consistent within and between years and dominated over diffusion effects. Ignoring variations in advective losses resulted in artificially elevated mortality estimates. Obtaining accurate estimates of larval mortality in the small system we studied was more than just a trivial problem despite the many simplifying advantages. Obtaining accurate estimates of larval mortality in larger ocean systems with more dispersed populations is doubtful.
\end{abstract}

\section{INTRODUCTION}

There are few exceptions to the rule that year-class strength in marine fish stocks bears, at best, a weak relationship to the spawning population size (Rothschild 1986). Large year-classes frequently result from small spawning populations and vice versa (Lasker 1975). The prevailing hypothesis that variations in mortality during early larval development are responsible for variations in subsequent recruitment (Jones 1973) is implicit in the so called 'critical period' hypothesis (Hjort 1914, 1926) and its various derivatives: the match-mismatch hypothesis (Cushing 1972, 1975); the stability hypothesis (Lasker 1975, Tilseth \& Ellertsen 1984, Peterman \& Bradford 1987); the safe-site hypothesis (Frank \& Leggett 1982, Leggett et al. 1984); the transport hypothesis (Pearcy 1962, Nelson et al. 1977, Baily 1981); and the drift and nour-

- Contribution to the programme of GIROQ (Group interuniversitaire de recherches océanographiques du Québec)

- Correspondence to: Bedford Institute of Oceanography, Box 1006, Dartmouth, Nova Scotia B2Y 4A2, Canada ishment hypotheses (Sinclair et al. 1985). However, there are few direct field estimates of larval mortality with which to address these hypotheses. Estimates of mortality are seldom based on multiple samples, and those that do exist show a range and variability that reflect both natural variation and sampling biases (gear type, sampling frequency, spatial and temporal resolution etc.). These sources of bias have already been highlighted by Cushing (1986) and Frank (1988) in questioning the interpretation of data used to challenge some of the above hypotheses.

The frequency of field sampling for larval fish typically ranges from once every 4 to once every $14 \mathrm{~d}$ (Dahlberg 1979). In addition, the majority of the published studies concerned with larval mortality typically used large scale (spatial and temporal) sampling designs that operated under the assumptions that: (1) the target population would be adequately sampled; (2) immigration or production of new larvae would be either nil, or positive but constant; (3) population dispersion (diffusion and advection) would not bias the mortality estimates; and (4) the size of individuals in the populations would reflect their age. The failure of these assumptions to be met may be responsible for the 
paucity of clear and direct evidence that either corroborates or rejects the hypotheses relating recruitment to larval mortality (Taggart \& Leggett 1987a).

The difficulty of estimating natural mortality in the field is the major barrier to adequate tests of the various larval mortality-recruitment hypotheses (Ware 1975). If they are to be tested, then larval mortality must be accurately quantified (Hewitt et al. 1985). Adequate tests require estimates of mortality that account for biases in measures of abundance introduced by sampling gear and sampling design.

In studying the population dynamics of larval capelin Mallotus villosus in eastern Newfoundland we have demonstrated that unbiased abundance estimates of larvae and various other planktonic taxa can be obtained coincidently (Taggart \& Leggett 1984), and that biases in the estimates attributed to sampling design and larval behaviour could be minimized (Taggart \& Leggett 1987b). In this study we evaluate, in light of the above assumptions concerning mortality estimation, the short-term mortality rate of capelin larvae during early drift and the degree of variation in the mortality estimates.

Several major advantages accrue when using capelin in a small coastal embayment for studying both shortterm larval mortality and the various assumptions concerning population dynamics during early larval drift: (1) the beach-spawning behaviour of capelin provides large numbers of eggs and larvae that are initially nondispersing (pre-emergent) and have a relatively narrow size and age distribution; (2) the pre-emergent larval population can be censused prior to the initiation of oceanic drift (emergence); (3) emergence of highly concentrated larval populations is nearly instantaneous and is triggered by onshore wind events that are easily monitored; (4) coastal embayments are geographically isolated from egg and larval populations at other locations; (5) embayments provide semi-enclosed and defined areas where the population dynamics of postemergent larvae during their early drift can be monitored, and where the immigration of censused larvae emerging from the beach and the emigration (advection) of larvae out of the embayment can be monitored at the same time.

\section{MATERIALS AND METHODS}

Study site. The study was conducted at Bryants Cove $\left(47^{\circ} 40.5^{\prime} \mathrm{N}, 53^{\circ} 11.0^{\prime} \mathrm{W}\right)$, Conception Bay, Newfoundland. The cove is a small embayment approximately $1 \mathrm{~km}$ long and $1 \mathrm{~km}$ wide at its mouth, at which point depth exceeds $20 \mathrm{~m}$ (Fig. 1). The principal spawning location for capelin is the fine-gravel beach at the head of the cove where the adhesive eggs are deposited and

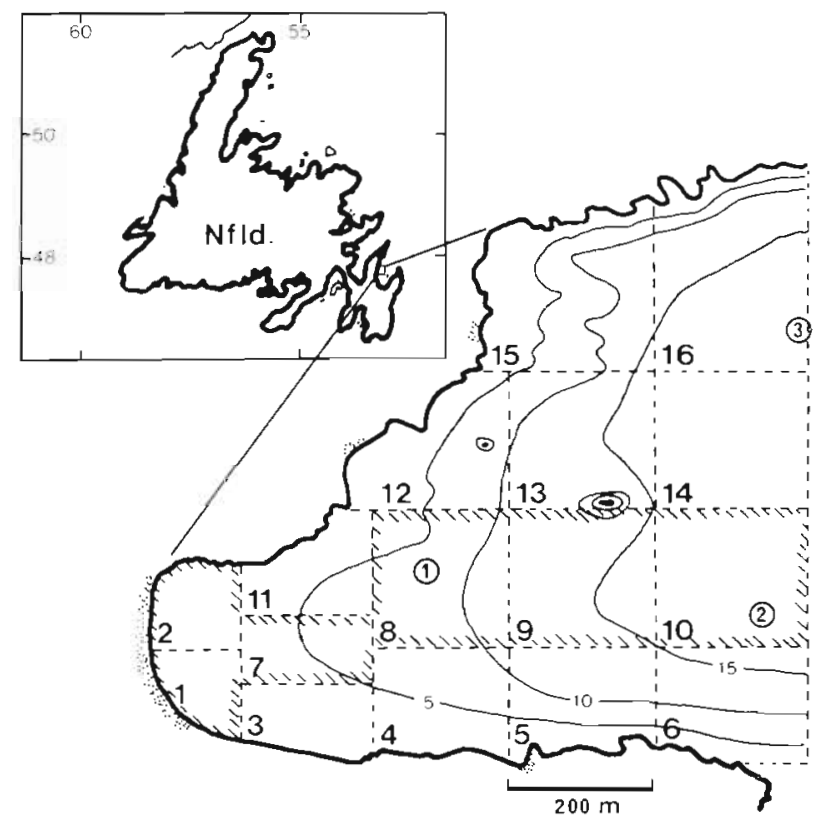

Fig. 1. Bryants Cove in Conception Bay, Newfoundland (Nfld.) detailing depth $(\mathrm{m})$, and positions of the grid survey stations (Cells 1 to 16), the transect survey stations (hatched), and the 3 current meter moorings ( 1 to 3 , encircled). Capelin spawning beaches are marked by stippling. (After Taggart \& Leggett 1987b)

incubate in the intertidal sediments. Larvae hatch in the sediments and emerge into the water column coincident with onshore winds (Frank \& Leggett 1981a, b, Taggart \& Leggett 1987b).

Pre-emergent larval sampling. The abundance of pre-emergent capelin larvae (hatched larvae in the beach sediments) was sequentially assessed every 1 to $2 \mathrm{~d}$ by stratified-random sampling of the intertidal area of spawning beaches at the cove in 1982 and 1983. The beaches were sampled 10 times in 1982 and 19 times in 1983. The main spawning beach $\left(1987 \mathrm{~m}^{2}\right)$ at the head of Bryants Cove (Fig. 1) was divided into 7 (1982) or 8 (1983) zones, each sub-divided into a high-, mid-, and low-tide section (HT, MT, LT). Pre-emergent larvae were sampled by coring with a $5.5 \mathrm{~cm}$ diameter corer (Frank \& Leggett 1981a) at one randomly chosen location within each zonal section during low tide. The depth of each core was recorded and the sample was preserved in $4 \%$ formalin-seawater buffered with sodium-borate. Each sample was washed in the laboratory in a $75 \%$ glycerol-water settling column to separate the sediments from the hatched larvae. Larvae were removed from each sample and counted.

Bryants Cove contains 3 small peripheral beaches where capelin spawn in some years. The intertidal sections of two of these $\left(348 \mathrm{~m}^{2}\right.$ adjacent to Cell 5; 147 $\mathrm{m}^{2}$ adjacent to Cell 12; Fig. 1) were routinely sampled 
in 1982 and 1983. A third beach $\left(107 \mathrm{~m}^{2}\right.$ adjacent to Cell 15) was sampled only in 1983 as no spawning occurred there in 1982.

Depth-standardized estimates of the areal density (A; larvae $\mathrm{cm}^{-2}$ ) of pre-emergent larvae in samples taken in each section ( $\mathrm{s}$ ) of beach zone $(\mathrm{z})$ were made by calculating:

$$
A_{z s}=\frac{T C_{z s}\left(\bar{D}_{z} / D_{z s}\right)}{C A}
$$

where $\mathrm{TC}=$ number of larvae in the sample; $\overline{\mathrm{D}}=$ average core depth; $\mathrm{D}=$ core depth; $\mathrm{CA}=$ area of the coring device $\left(23.76 \mathrm{~cm}^{2}\right)$. All estimates were standardized because some cores were shallower than the average, and larvae are known to be homogeneously distributed (vertically) to a depth of $14 \mathrm{~cm}$ (Frank \& Leggett 1981b). We observed eggs and larvae at depths of $20 \mathrm{~cm}$. However, experiments conducted in 1983 revealed that mixing of the beach sediments occurred to an average depth of $10 \mathrm{~cm}(\mathrm{SD}=5.3 \mathrm{~cm})$. The total number of preemergent larvae $(\mathrm{P})$ in the beach at the time of sampling (t) was expressed as larvae/cove water-volume:

$$
P_{t}=\frac{\left(10^{G M_{t}}-1.0\right) T B A}{V C}
$$

where TBA = area of all beaches sampled $\left(\mathrm{cm}^{2}\right) ; \mathrm{VC}=$ cove water-volume; $\mathrm{GM}=$ geometric mean of the areal density estimates (Frank \& Leggett 1981b):

$$
\mathrm{GM}_{\mathrm{t}}=\frac{\sum_{z=1}^{\mathrm{z}} \sum_{\mathrm{s}=1}^{\mathrm{s}} \log _{10}\left(\mathrm{~A}_{z s}+1.0\right)}{\mathrm{ZS}}
$$

Post-emergent larval sampling. In 1981 to 1983 capelin larvae were collected at a suite of either 6 (Fig. 1, hatched grid) or 16 stations (Fig. 1, complete grid) within the cove using an $80 \mu \mathrm{m}$ plankton net, a customized plankton pump (Taggart \& Leggett 1984), and the sampling design detailed in Taggart \& Leggett (1987b) which is briefly described below. Samples were collected at least daily between late June and early August of each year except when equipment failure or weather conditions made sampling impossible. Sampling frequency was increased to 3 or 4 times per day immediately following onshore winds when larval emergence was pronounced.

In 1981 we systematically sampled $1 \mathrm{~m}^{3}$ from each of 4 discrete depth strata $(0.5,2,5$, and $9 \mathrm{~m}$ where permitted by bathymetry) at each of the 16 grid stations. Each sample was horizontally integrated by sampling over the area of the station while under way. A total of 38 sequential surveys (1634 samples) were completed in 1981. In 1982 and 1983 we sampled 1 to $2 \mathrm{~m}^{3}$ in each of 3 discrete depth intervals ( 0 to $2 \mathrm{~m}, 2$ to $5 \mathrm{~m}$, and 5 to $9 \mathrm{~m}$, where possible) either on the 16 station grid or on the 6 station transect oriented along the main axis of the cove
(Taggart \& Leggett 1987b). Sampling was horizontally and vertically integrated by moving the boat within the confines of the station while undulating the intake between the limits of the specified stratum. There were 31 sequential surveys in 1982 (283 samples) and 68 surveys in 1983 (1622 samples). Samples were preserved immediately following collection in $4 \%$ formalin-seawater buffered with sodium borate. All capelin larvae from all samples were removed and enumerated in the laboratory.

Larval emergence (immigration). The number of preemergent larvae in the beach sediments could not be estimated as frequently as, nor coincidently with, the estimates of post-emergent larvae in the cove because of logistical limitations. Therefore, estimates of preemergent larval density coincident with estimates of post-emergent larval density were developed by exponential interpolation between the sequential $\left(t_{1}\right.$ to $\left.t_{2}\right)$ beach surveys:

$$
P_{t}=P_{t_{1}} e^{b\left(t_{1}-t\right)}
$$

where $\mathrm{P}_{\mathrm{t}_{1}}$ is from Eq.(2) above, and where:

$$
b=\frac{\left(\ln P_{t_{2}}\right)-\left(\ln P_{t_{1}}\right)}{t_{2}-t_{1}}
$$

It was necessary to estimate: (1) the number of larvae resident in the beach at all times, assuming none had emerged (the projected population), and (2) the export of larvae from the beach (immigration to the cove) during any survey interval ( $t_{1}$ to $\left.t_{2}\right)$. The pre-emergent larval population increases with the interval between onshore winds because larvae are continuously hatching and accumulating in the sediments (Frank \& Leggett $1981 \mathrm{a}$ ). We therefore calculated the rate of population increase ( $\mathrm{r}$ ) in the beach by using the sequential density estimates when the larval population in the beach was increasing (periods dominated by offshore winds):

$$
r_{t_{2}-t_{1}}=\frac{P_{t_{2}}-P_{t_{1}}}{t_{2}-t_{1}}
$$

The accumulated rate of increase (R) was subsequently estimated by fitting the logistic equation to the observed rates (r) accumulated following median spawning (Fig. 2):

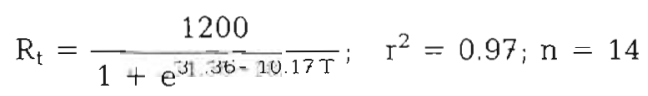

where $T=$ the natural logarithm of days post-median spawning. The projected size of the pre-emergent population was therefore based on the functional relation between the cumulative rate of increase of the population and post-median spawning time (Fig. 2). Two spawning cohorts contributed to the larval population in 1982 and only one contributed in 1983. 


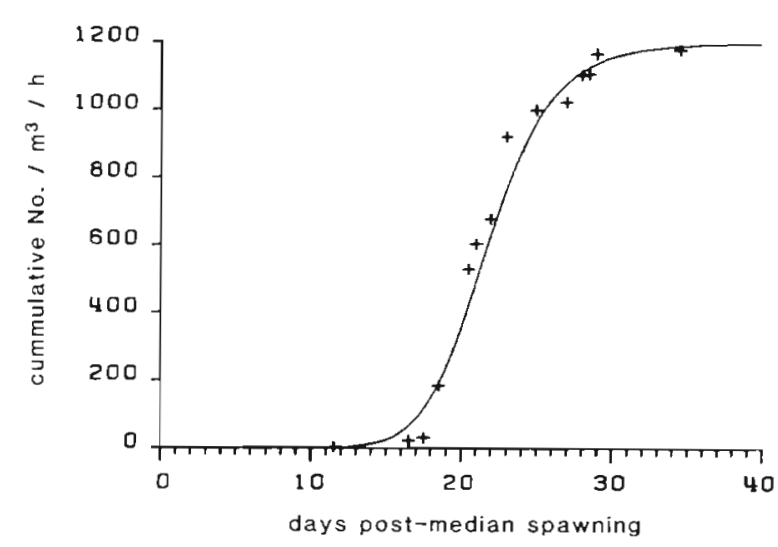

Fig. 2. Mallotus villosus. Plot showing relation between cumulative rate of increase of pre-emergent larvae (number $\mathrm{m}^{-3} \mathrm{~h}^{-1}$ ) and time (d) since median spawning in 1982 and 1983. The logistic equation describing the relation is given in Eq. (7) (see text)

Subsequently, a time series of the projected larval population (PP) in the beach at time (t) was estimated at hourly intervals following the first post-median spawning density estimate:

$$
P P_{t}=P_{t=0}+\sum_{t}^{t=0} R_{t}
$$

The number of larvae emerging (NP) over a given interval was then:

$$
N P_{t_{2}-t_{1}}=\left(P P_{t_{2}}-P_{t_{1}}\right)-\sum_{i=0}^{i=t_{2}-1}\left(P P_{t=i}-P_{t=i}\right)
$$

Post-emergent larvae.Total abundance estimates of post-emergent larval capelin during each sampling survey were made by summation over all stations of the station-stratum volumes multiplied by the corresponding station-stratum concentration. Estimates of the density in each stratum in 1981 were made by taking the arithmetic mean of vertically adjacent discretedepth density estimates. Estimates at each station were corrected for bias attributable to diel migration of larvae below the $9 \mathrm{~m}$ maximum sampling depth, and below the 0 to 2 stratum at the 3 outermost stations along the southside of the cove (Taggart \& Leggett $1987 b)$. When only the 6-station transect was sampled, the multiple regression models described in Taggart \& Leggett (1987b) were used to determine density estimates for the complete station-grid. The average density for the cove was calculated by dividing the total abundance estimate by the cove volume $(5.54 \times$ $10^{6} \mathrm{~m}^{3}$ ).

Diffusion-advection (emigration). Two dye diffusion-advection experiments were conducted in 1982 to identify the relative influence of advection and diffusion on horizontal dispersion. The experiments also permitted a comparison of the advective trajectory with the circulation pattern described in Taggart \& Leggett (1987b). A Rhodamine-B liquid tracer (BASF: Bazazol Red 71L) was monitored with a Turner 111 fluorometer system (Carter 1974) supplied with seawater at 3 l min $^{-1}$ by a submersible pump located at $0.5 \mathrm{~m}$ depth. Experiments were conducted on $25 \mathrm{Jul}$ and $15 \mathrm{Aug}$ 1982 using initial dye concentrations of $3.33 \times 10^{8}$ and $2.8 \times 10^{7}$ ppb respectively, released immediately adjacent to the main spawning beach. A series of fluorometric surveys, each comprising a number of transects oriented along the main axis of the cove and at $90^{\circ}$ to the main axis were subsequently conducted. Synoptic isopleths of dye distribution were produced by referring all transects and times to the time and position of the maximum concentration observed for the series.

Lowpass-filtered current meter data recorded at 3 stations in Bryants Cove in 1982 and 1983 (Fig. 1) were used for calculating advective transport. Current meter moorings and data filtering are described in detail in Taggart \& Leggett (1987b). Depth-averaged measures of transport at each station during each survey interval $\left(t_{1}\right.$ to $t_{2}$ ) were made by calculating the average current velocity (VEC) at each mooring station:

$$
\mathrm{VEC}_{\mathrm{t}_{2}-\mathrm{t}_{1}}=\left(\overline{\mathrm{U}}^{2}+\overline{\mathrm{V}}^{2}\right)^{1 / 2}\left(\mathrm{t}_{2}-\mathrm{t}_{1}\right)
$$

where $\bar{U}$ (cross-shore) and likewise for $\bar{V}$ (longshore) are:

$$
\bar{U}=\frac{\left(\sum_{t_{1}}^{t_{2}} U_{s}\right) / t_{2}-t_{1}+\left(\sum_{t_{1}}^{t_{2}} U_{b}\right) / t_{2}-t_{1}}{2}
$$

where $U_{s}$ and $U_{b}\left(V_{s}\right.$ and $\left.V_{b}\right)=$ hourly estimates of the $\mathrm{U}$ (V) component of velocity at the surface (s) and bottom (b) current meters. The single current meter at Stn 1 was taken as representative of the entire water column at Stn 1.

Population loss estimates. Five different estimates of the proportion of post-emergent larvae lost from the cove were calculated to evaluate the effect of various assumptions regarding immigration and emigration on mortality estimates. The first estimate $\left(L_{1}\right)$ was simply the proportion lost during the survey interval ( $t_{1}$ to $\left.t_{2}\right)$ :

$$
L_{1}=1-\left(\frac{N_{t_{2}}}{N_{t_{1}}}\right)
$$

where $\mathrm{N}=$ density of larvae in the cove. The estimate assumes either (1) no immigration to, or emigration from, the larval population, or (2) equivalent immigration and emigration. There were no estimates of preemergent larvae in 1981, nor were there any current meter data. Therefore, the remaining 4 estimates $\left(\mathrm{L}_{2}\right.$ to $\mathrm{L}_{5}$ ) were calculated for 1982 and 1983 only.

The second loss estimate $\left(\mathrm{L}_{2}\right)$ included a simple measure of immigration of emergent larvae from the beach: 


$$
L_{2}=1-\left(\frac{N_{t_{2}}}{N_{t_{1}}+N P_{t_{2}-t_{1}}}\right)
$$

where immigration (NP) was assumed to be instantaneous and larvae were asmussed to be homogeneously distributed throughout the cove.

The third estimate $\left(L_{3}\right)$ included a simple measure of emigration of post-emergent larvae from the cove during the census interval:

$$
\mathrm{L}_{3}=1-\left(\frac{\mathrm{N}_{\mathrm{t}_{2}}}{\mathrm{~N}_{\mathrm{t}_{1}}-\left[A D \mathrm{~A}_{\mathrm{t}_{2}-\mathrm{t}_{1}}\left(\mathrm{~N}_{\mathrm{t}_{1}}\right)\right]}\right)
$$

where emigration was assumed to be proportonial to volume of water advected out of the cove (ADV), and larvae were again assumed to be homogeneously distributed. This approach also assumes that recently hatched larvae are horizontally transported passively by the currents as reported by Fortier \& Leggett (1982). Advective loss was estimated using the cross-shore current (U) from the surface and bottom current meters located at the outflow and inflow boundaries of the cove and resolved normal to the seaward boundary. A simple horizontal flow model was chosen because there was little evidence of a vertically structured current shear, and horizontal current variation was greater than vertical variation (Taggart \& Leggett 1987 b). Our choice was also conditioned by the annual consistency in the horizontal flow field. The simplest flow model is also often the most appropiate (Lam et al. 1984).

The proportion of cove volume advected out of the cove (ADV) during larval survey intervals was:

$$
\mathrm{ADV}_{\mathrm{t}_{2}-\mathrm{t}_{1}}=\mathrm{CV}-\left(\frac{\mathrm{U}_{\mathrm{t}}}{\left|\mathrm{U}_{1}\right|+\left|\mathrm{U}_{0}\right|} \mathrm{CB}\right)
$$

where $\mathrm{CB}=$ cross-sectional area of the seaward boundary of the cove. $U_{i}$ and $U_{o}$ are the depth-averaged current at the inflow (Stn 3) and at the outflow (Stn 2) calculated using Eq. (11) above.

The fourth loss estimate $\left(\mathrm{L}_{4}\right)$ included simple measures of larval immigration and emigration (a combination of $\mathrm{L}_{2}$ and $\mathrm{L}_{3}$ ):

$\mathrm{L}_{4}=1-\left(\frac{\mathrm{N}_{\mathrm{t}_{2}}}{\mathrm{~N}_{\mathrm{t}_{1}}+\mathrm{NP}_{\mathrm{t}_{2}-\mathrm{t}_{1}}-\left(A D \mathrm{~V}_{\mathrm{t}_{2}-\mathrm{t}_{1}}\left[\mathrm{~N}_{\mathrm{t}_{1}}+\mathrm{NP}_{\mathrm{t}_{2}-\mathrm{t}_{1}}\right]\right)}\right)$

The final estimate of the proportion of post-emergent larvae lost $\left(\mathrm{L}_{5}\right)$ was a refinement of $\mathrm{L}_{4}$ without the restrictive assumptions placed on immigration and emigration. The estimate was from a simple multiplebox model and 'marching' of the larvae through the boxes or cells according to the observed depth-averaged horizontal current pattern, an interpolated flow field, conservation of mass flow among the cells, and time-based immigration of larvae from the beach.

The marching model was developed using a doubleprecision FORTRAN program. The model incorporated
15 cells, identical to the grid stations employed for sampling surveys (Fig. 1), with the exception of Cell 7 which was partitioned equally and added to Cell 3 to the south and Cell 11 to the north. The velocity field across the 15 cells during each survey interval was interpolated and extrapolated using the algorithm of Lam et al. (1984; p. 38) and the depth- and timeaveraged $U$ - (east-west) and $V$ - (north-south) components of current (Eq. 11) measured at the 3 current meter stations. The $U$ - and $V$-components were resolved normal to the cell boundaries. The influence of each observed velocity vector on the interpolated and extrapolated vectors was proportional to the euclidean distance between the observed and the interpolated or extrapolated cell vector. The interpolated flow field will not generally allow for the conservation of mass, particularly where there is a variable depth profile (Lam et al. 1984). Conservation of mass was therefore satisfied by first calculating the volume of water imported from seaward $(-U)$ at Cells 14 and 16 by muliplying the seaward boundary area of the cells by their respectively observed and interpolated U-components. Export to adjacent cells was then determined by dividing the imported volume according to the relative proportions of the interpolated or observed U- and Vcomponents of the exporting cell. This process proceeded sequentially across all cells in a landward direction from the inflow side, and continued in a seaward direction ending at the outflow side. Total export from the cove was therefore weighted toward measures of total import from outside the cove.

The marching consisted of initializing each cell with the total number of capelin larvae observed in that cell at time $\mathrm{t}=1$, and then iterating at $1 \mathrm{~min}$ steps for the duration of the survey interval. At each iteration a proportion of the larval population in each cell was exported to adjacent cells (or out of the cove) according to the proportion of cell water volume exported. The 'background' import of larvae into Cells 14 and 16 from seaward during each iteration was dertermined by the initial density of larvae in those cells at $t=1$ and remained constant for the duration of the interval. Larvae were imported from the main beach into Cells 1 and 2 (adjacent the main beach) during each iteration using the estimate of NP (Eq. 9) distributed linearly over the interval. The proportion of NP entering Cells 1 and 2 was determined by the proportion of the beach area adjacent the cells (37.5 and $62.5 \%$ respectively). Marching procedures performed by importing larvae from the 3 peripheral beaches into their respectively adjacent made only slight differences in the number of larvae advected out of the cove because these beaches represented only 13,6 and $4 \%$ respectively of the total beach area. As we detail below (Results: Diffusionadvection) diffusion of larvae beyond the cove bound- 
aries was insignificant relative to advection, and was therefore not considered in the marching procedure.

At the end of each marching interval $\left(t_{2}\right)$ an estimate of the expected larval density (i.e. assuming no mortality) was output (NE), and $I_{5}$ was calculated:

$$
\mathrm{L}_{5}=1-\left(\frac{\mathrm{N}_{\mathrm{t}_{2}}}{\mathrm{NE}_{\mathrm{t}_{2}}}\right)
$$

All loss estimates were standardized for the interval between sequential density estimates, and instantaneous mortality $\left(z_{1}, z_{2}, z_{3}, z_{4}\right)$ was calculated for each of $L_{1}$, $\mathrm{L}_{2}, \mathrm{~L}_{3}$, and $\mathrm{L}_{4}$ respectively using:

$$
\mathrm{z}=\frac{\left(\ln \mathrm{N}_{\mathrm{t}_{2}}\right)-\left(\ln \mathrm{N}_{\mathrm{t}_{1}}\right)}{\mathrm{t}_{2}-\mathrm{t}_{1}}
$$

where tis in hours and where $\mathrm{N}_{t_{1}}$ and $\mathrm{N}_{t_{2}}$ were corrected (where applicable) for immigration and emigration. Instantaneous mortality for $\mathrm{L}_{5}$ was calculated using:

$$
z_{5}=\frac{\left(\ln N_{t_{2}}\right)-\left(\ln N E_{t_{2}}\right)}{t_{2}-t_{1}}
$$

Daily mortality estimates $\left(M_{1}\right.$ to $\left.M_{5}\right)$ were calculated from the appropriate $\mathrm{z}$ values:

$$
M=1-\left(e^{z}\right)^{24}
$$

The influence of the various assumptions employed in calculating the mortality estimates were examined by comparing the number of positive estimates realized with the number possible, their averages, the degree of variation in each, and by correlation analysis of the estimates and the estimates of immigration and emigration.

\section{RESULTS}

\section{Larval densities}

The average density of pre-emergent larvae was 3.5 fold greater in $1982(78.69, \mathrm{n}=10)$ than in $1983(22.42$, $\mathrm{n}=19$ ). We believe this to be a function of the greater number of samples taken later in 1983 when preemergent larvae were less abundant, although sampling effort (estimates $\mathrm{d}^{-1}$ ) was virtually identical 10.52 . $1982 ; 0.54,1983)$. Although estimates were based on the geometric average of 27 and 33 samples in 1982 and 1983 respectively, the $95 \%$ confidence intervals were large, representing as much as $40 \%$ of an estimate, and indicated an over-dispersed spatial distribution of pre-emergent capelin (Fig. 3). Similar findings were reported by Frank \& Leggett (1981a).

The average density of post-emergent capelin larvae showed intra-annual variation of 1 to 2 orders of magnitude in each year (Fig.4). The annual average density increased sequentially from $20 \mathrm{~m}^{-3}$ in 1981 , to $35 \mathrm{~m}^{-3}$ in 1982 , and to $42 \mathrm{~m}^{-3}$ in 1983.

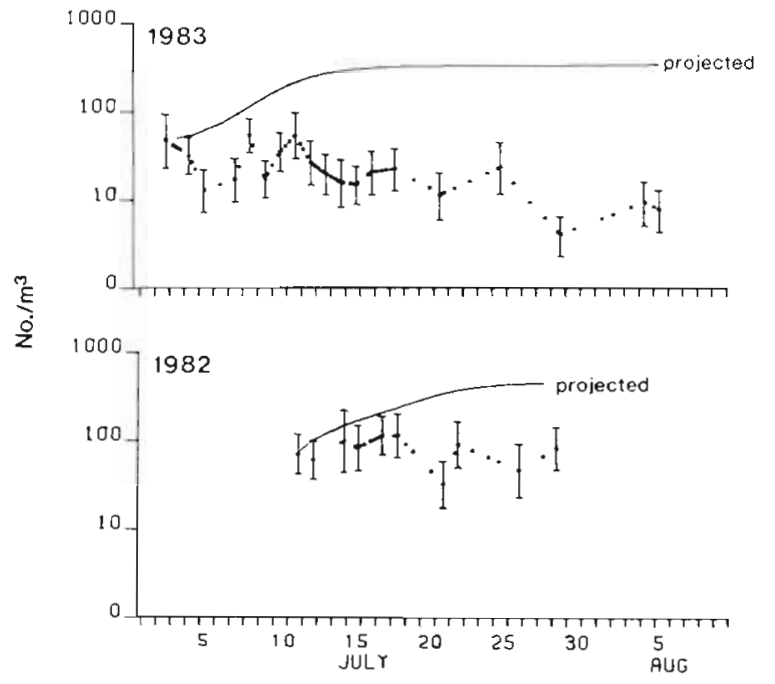

Fig. 3. Mallotus villosus. Time series of observed, interpolated (isolated points), and cumulative-projected pre-emergent capelin larvae population density (larvae/cove volume) in beaches at Bryants Cove in 1982 and 1983. Vertical bars depict $95 \%$ confidence intervals around observed estimates

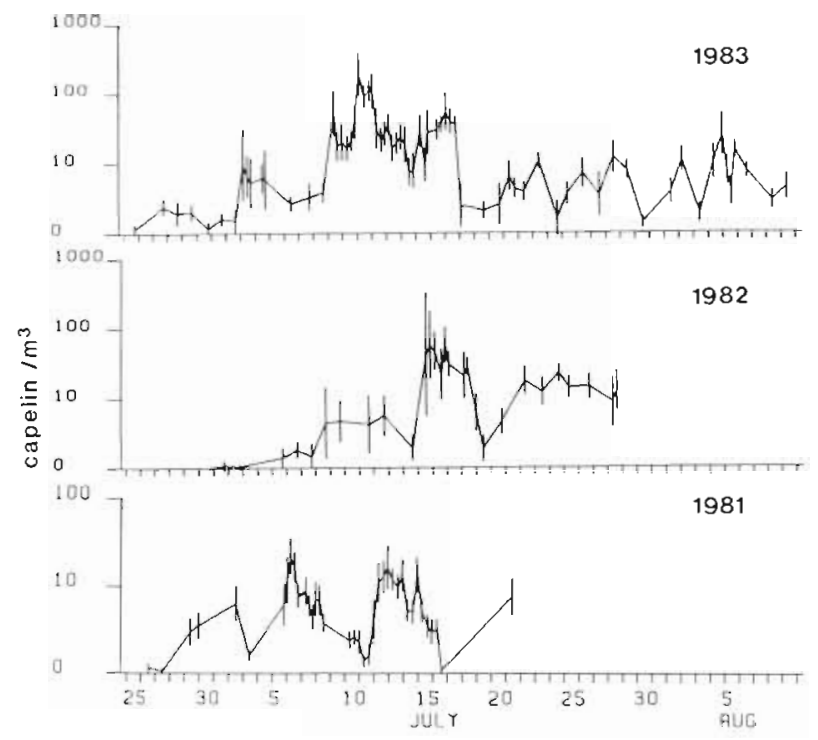

Fig. 4. Mallotus villosus. Time series of average density $( \pm 2$ SE) of capelin larvae in Bryants Cove in 1981 to 1983

\section{Diffusion-advection}

The rate of diffusion, as determined from the temporal decrease in the maximum concentration of dye (centre of patch) in each experiment, closely followed the third-power law (Fig. 5) that is typical for oceanic diffusion studies (Weidemann 1973). The relations between concentration $C$ (ppb) and time (h) were statistically identical in each experiment $\left(\alpha_{0.05}\right)$ : 


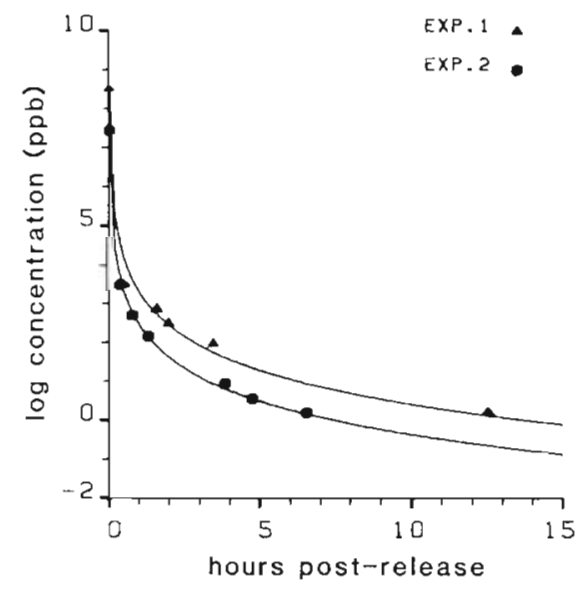

Fig. 5. Plot showing relation between concentration of rhodamine dye (ppb) and time (h) following dye release in 2 experiments conducted in 1982 in Bryants Cove. Slopes of the fitted relations (solid line) are identical $(p<0.05)$

$\begin{array}{ll}\text { Expt } 1 & \log C=-2.90 \log h+3.32 \\ \text { Expt } 2 & \log C=-2.84 \log h+2.49\end{array}$

Concentration isopleths demonstrated that advection dominated over diffusion at the scale of the experi- ments (Fig. 6). In both experiments (only Expt 2 is shown) the trajectory of dye was seaward along the south side of the cove and was consistent with the average circulation deduced from current meter data (Taggart \& Leggett $1987 \mathrm{~b}$ ). The rate of dye advection $\left(6.2 \mathrm{~cm} \mathrm{~s}^{-1}\right)$ was similar to the average current speed $\left(6.0 \mathrm{~cm} \mathrm{~s}^{-1}\right)$ measured with current meters (Taggart \& Leggett $1987 \mathrm{~b}$ ). The concentration isopleths were consistent with the similarity hypothesis of diffusion which states that as the concentration decreases the scaled distribution relative to the centre maintains shape (Okubo 1980). The cross-flow (N-S) concentration distribution remained Gaussian while the along-flow (E-W) distribution evolved an upstream skew (Fig. 7), demonstrating the dominance of advection in the seaward transport. These results permitted us to consider advective processes only in evaluating larval emigration from the cove.

Depth- and time-averaged transport estimates (Eq. 4) at each current meter station during each survey interval were significantly correlated with each other, with the proportion of cove volume advected (ADV), and with the length of the sampling survey interval (ELAP) (Table 1). Consequently, the estimates of
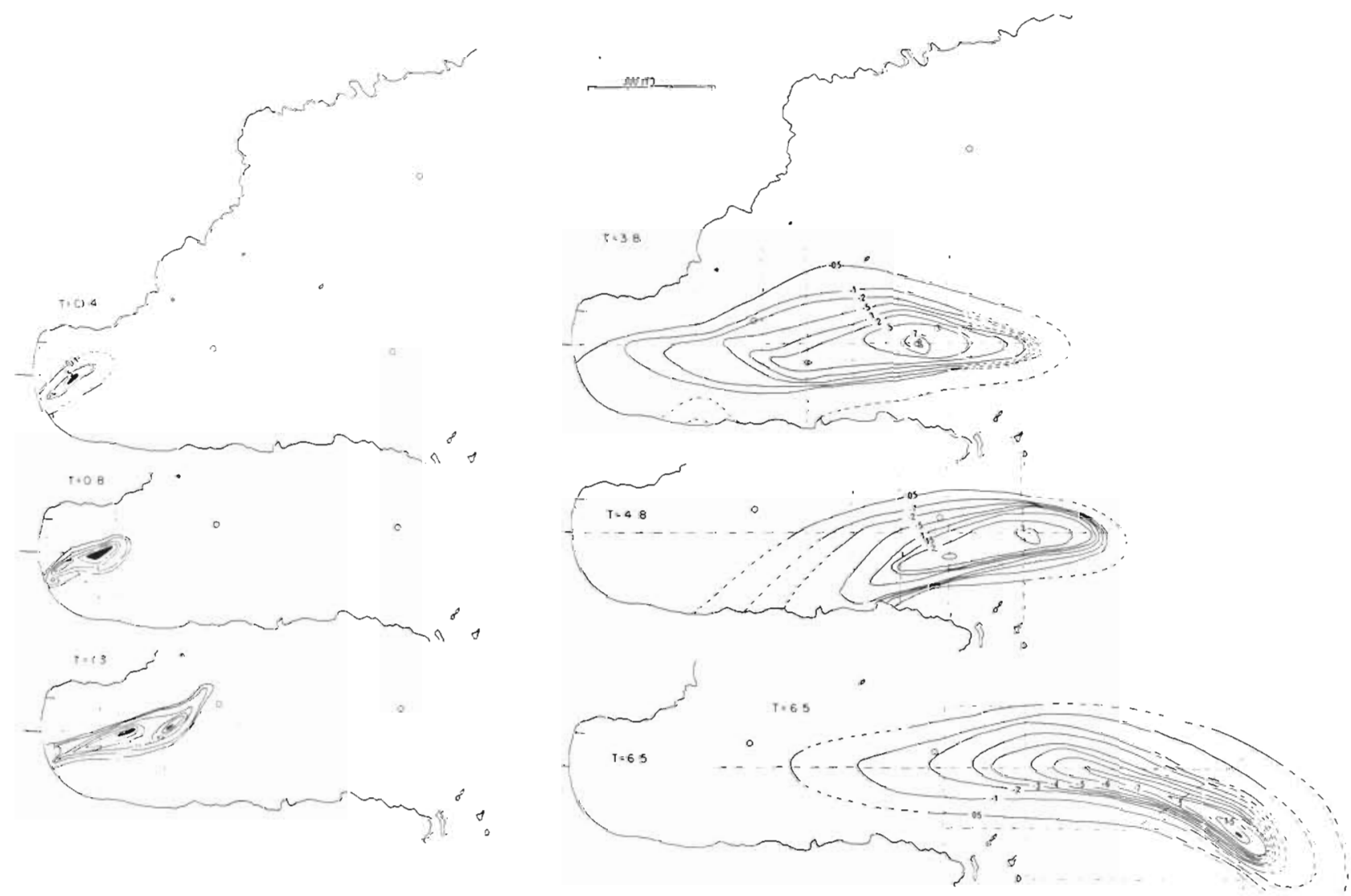

Fig. 6. Isopleths of rhodamine dye concentration $(\mathrm{ppb})$ at various post-release times ( $\mathrm{T}=$ hours) during the second dye experiment in Bryants Cove in 1982. Straight dashed lines show the survey transects from which the isopleths were constructed. Interpolated isopleths are dashed 

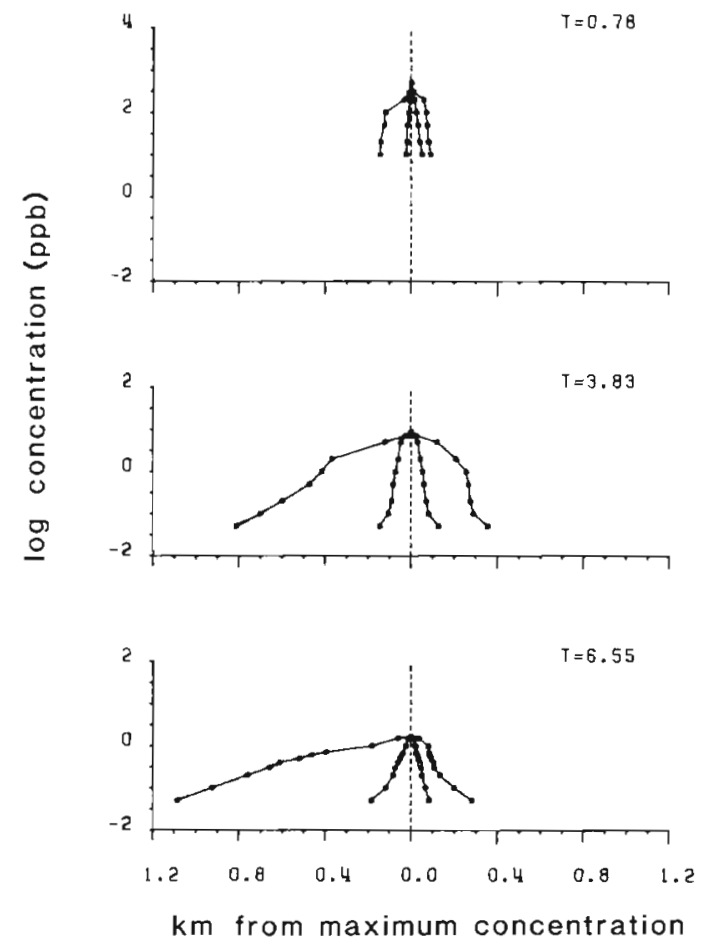

Fig. 7. Plot showing relation between rhodamine dye concentration (log $\mathrm{ppb}$ ) and distance $(\mathrm{km})$ from the maximum concentration in the cross-flow (N-S, inner curve) and in the along-flow (W-E, outer curve) directions at various postrelease times ( $\mathrm{T}=$ hours) during the second dye experiment conducted in 1982

advective loss (Eq. 9) and the length of survey intervals were also highly correlated (Table 1 ; Fig. 8). This illustrates that advective transport was consistent within and between years. However, for 1 interval in 1982, and for 4 intervals in 1983, the current meters uniformly recorded either landward or seaward flow. As conservation of mass could not be satisfied using the data, the proportion of cove volume exported was set to zero (Fig. 8).

During the last 9 sampling surveys in 1983 there were no current meter data and advective loss was

Table 1. Pearson correlation matrix of total water mass transport at each of the 3 current meter stations (Stns 1,2 and 3; Fig. 1), proportion of cove volume advected out of Bryants Cove (ADV), and time interval between sampling surveys (ELAP) in 1982 and 1983

\begin{tabular}{|cccccccc|}
\hline & & \multicolumn{6}{c}{$1982(\mathrm{n}=30)$} \\
& & ADV & $\operatorname{Stn} 1$ & $\operatorname{Stn} 2$ & $\operatorname{Stn} 3$ & ELAP \\
\hline & & & & & & & \\
& ADV & - & 0.777 & 0.913 & 0.807 & 0.780 \\
1983 & Stn 1 & 0.764 & - & 0.775 & 0.858 & 0.853 \\
$(\mathrm{n}=58)$ & Stn 2 & 0.922 & 0.772 & - & 0.714 & 0.757 \\
& Stn 3 & 0.874 & 0.893 & 0.855 & - & 0.830 \\
& ELAP & 0.739 & 0.893 & 0.771 & 0.870 & - \\
\hline
\end{tabular}

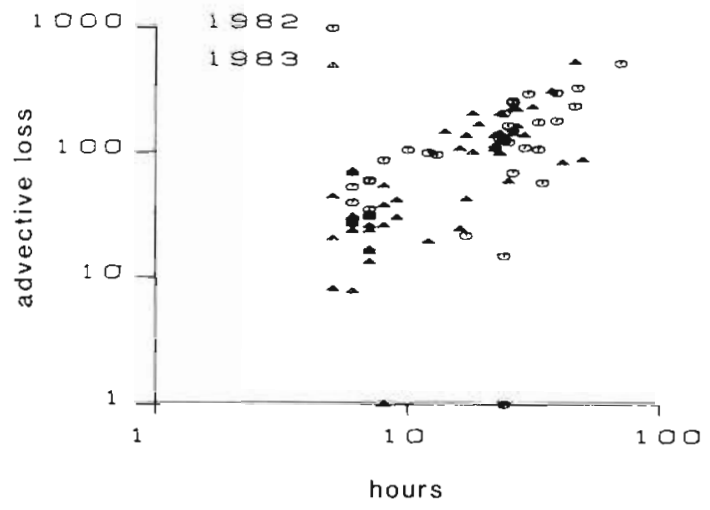

Fig. 8. Scatter diagram showing relation between advective loss (the percentage of cove water volume exported) and time interval between sampling surveys in 1982 and 1983

estimated by regressing the percentage of volume advected out of the cove (ADV) on the length of the survey intervals (ELAP). The model (ADV $=6.21$ ELAP $\left.-4.573 ; n=50, r^{2}=0.55\right)$ explained $64 \%$ of the variance in ADV when tested on the 1982 data $(n=28)$. Not surprisingly a model of the 1982 data $(\mathrm{ADV}=6.14$ ELAP -1.65$)$ was not significantly different from the 1983 model. Both models indicated that $100 \%$ of the cove volume was normally exchanged within $15 \mathrm{~h}$ and compare favourably with 19 h calculated from the average circulation (Taggart \& Leggett 1987b).

A total of 89 velocity fields were generated for use in the marching model for the 1982 and 1983 data. Twelve specifically chosen examples of the velocity fields (Fig. 9) illustrate that they conform well with the average circulation pattern demonstrated earlier (Taggart \& Leggett 1987b) and the flow trajectory resolved by the rhodamine dye experiments (Fig. 6). The sequential increases in velocity from the seaward to the landward cells illustrate the effect of mass-flow conservation when depth decreased in a landward direction. Exceptions to this generality did occur (e.g. 1983 Panels 1, 2, 3; Fig. 9), and some cells (e.g. 1982 Cells 2 to 5; Fig. 9) indicated a net flow through the land boundary which is clearly impossible. Additionally, shear zones were apparent (e.g. 1983 Panels 1, 2; Fig. 9) and show that continuity of the velocity field was not always maintained by the interpolation algorithm employed. The above inconsistencies resulted directly from the limited number of observation points in the cell field, and the interpolation algorithm.

\section{Larval population losses and mortality}

Approximately $50 \%$ of the $\mathrm{L}_{1}$ loss estimates calculated for 1981, 1982 and 1983 were negative, a result 

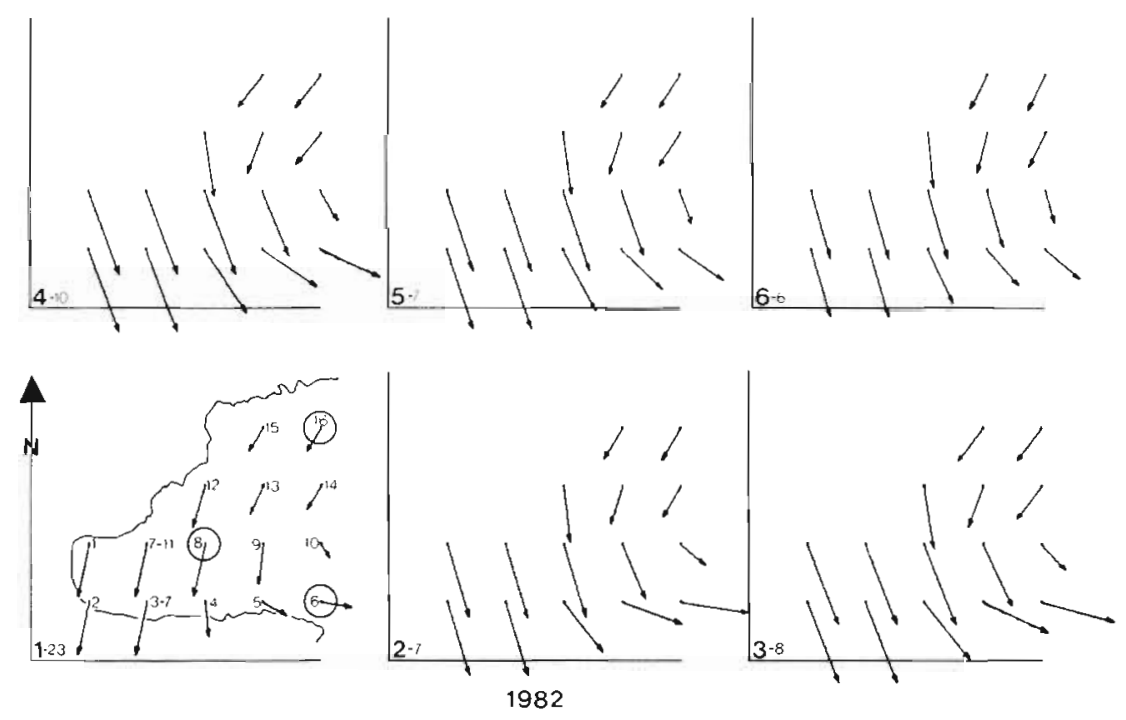

Fig. 9. Examples of interpolated and extrapolated current velocity fields in each of 15 cells in Bryants Cove during 6 sequential sampling survey intervals in 1982 (between $1600 \mathrm{~h}, 14 \mathrm{Jul}$ and $0500 \mathrm{~h}$, $17 \mathrm{Jull}$ and 1983 (between $0300 \mathrm{~h}, 12 \mathrm{Jul}$ and $1800 \mathrm{~h}, 13 \mathrm{Jul}$ ). Panels are numbered in sequence followed by the duration of the survey interval (h). Cell numbers corresponding to the survey grid and the positions of the observed velocities from current meters (encircled) are provided in Panel 1. Vector lengths represent the relative magnitude of the current, and dashed lines indicate zones of discontinuity in the velocity field
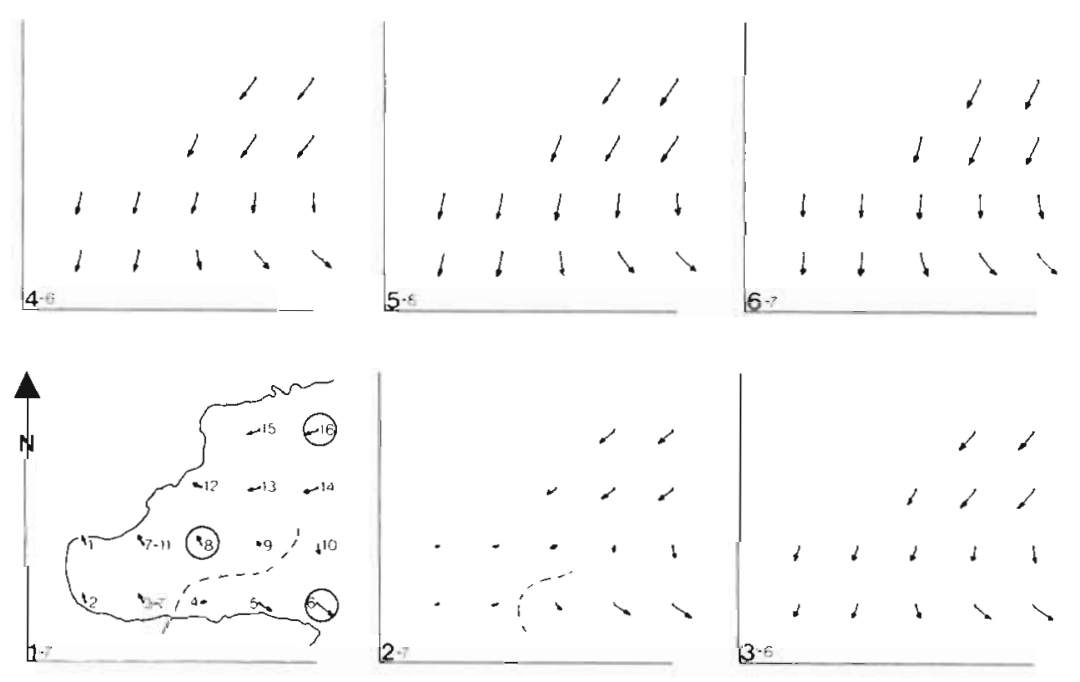

that illustrates the bias due to assuming zero (or equivalent) immigration and emigration. However, the annual averages of the mortality estimates $\left(M_{1}\right)$ were similar, ranging from 50 to $70 \%$ per day (Table 2). In comparison, $35 \%$ of the $\mathrm{L}_{2}$ loss estimates for 1982 and 1983 were negative. The number of positive estimates of $\mathrm{L}_{2}$ relative to $\mathrm{L}_{1}$ increased by ca $40 \%$, and the annual average daily mortality increased by ca $12 \%$. (65.7\% in 1982 , and $74.0 \%$ in 1983) when immigration was included in the calculations. There was a decrease of ca $70 \%$ in the number of $\mathrm{L}_{3}$ estimates that could be calculated in 1982 and 1983 relative to $\mathrm{L}_{1}$. Average daily mortality $\left(\mathrm{M}_{3}\right)$ was ca 10 to $20 \%$ lower relative to $\mathrm{M}_{2}$ (Table 2). Both of these results are attributable to the simplifying assumption of including only advective loss (emigration) in calculating the estimates. The greatest effect resulted when estimated loss by advec- tion exceeded $100 \%$ of the population, in which case instantaneous mortality $\left(z_{3}\right)$ could not be calculated, and hence $\mathrm{M}_{3}$ was indeterminate.

When simple corrections for both immigration and emigration were included there was no improvement in the number of loss estimates $\left(\mathrm{L}_{4}\right)$ relative to $\mathrm{L}_{3}$ in 1982 , although twice as many $\mathrm{L}_{4}$ estimates $(\mathrm{n}=20)$ relative to $\mathrm{L}_{3}(\mathrm{n}=11)$ were obtained in 1983 (Table 2). Furthermore, while the average $M_{4}(63.9 \%)$ was higher than $\mathrm{M}_{1}(52.9 \%)$ in 1982 , it was lower $(51.7$ vs $62.9 \%)$ in 1983. These results indicate that the influence of the 2 simplifying assumptions changed between years, with the caveat that there were only 3 estimates possible in 1982 .

The combined total of 97 sampling survey intervals in 1982 and 1983 provided only 40 positive estimates of $\mathrm{L}_{5}$. This result implies that the marching model was 
Table 2. Sample size ( $\mathrm{n}$ ), average (Av), standard deviation (SD), maximum (Max), and minimum (Min) statistics for the 5 different daily mortality estimates (Est) calculated for 1981, 1982 and 1983

\begin{tabular}{|c|c|c|c|c|c|c|c|c|c|c|c|c|c|c|c|}
\hline & & & 1981 & & & & & 1982 & & & & & 1983 & & \\
\hline Est & $\mathrm{n}$ & Av. & $\mathrm{SD}$ & Max & Min & $n$ & Av. & $\mathrm{SD}$ & $\operatorname{Max}$ & Min & $n$ & Av. & $\mathrm{SD}$ & Max & Min \\
\hline$M_{1}$ & 19 & 68.6 & 35.3 & 99.9 & 2.3 & 13 & 52.9 & 27.2 & 96.6 & 10.4 & 33 & 62.9 & 28.7 & 99.9 & 9.9 \\
\hline$M_{2}$ & & & & & & 19 & 65.7 & 26.2 & 99.8 & 10.4 & 45 & 74.0 & 23.0 & 99.9 & 11.9 \\
\hline $\mathrm{M}_{3}$ & & & & & & 3 & 43.5 & 29.0 & 72.5 & 14.5 & 11 & 64.9 & 32.6 & 99.9 & 1.7 \\
\hline $\mathrm{M}_{4}$ & & & & & & 3 & 63.9 & 17.8 & 75.1 & 43.4 & 20 & 51.7 & 35.6 & 99.9 & 0.6 \\
\hline$M_{5}$ & & & & & & 12 & 55.0 & 37.4 & 98.4 & 2.7 & 28 & 65.3 & 28.7 & 99.9 & 11.3 \\
\hline
\end{tabular}

inadequate, either because estimates of immigration and emigration were, in combination, either too high or too low, or that larval density estimates derived from each sampling survey were inaccurate. However, $23 \mathrm{~L}_{5}$ estimates could not be calculated either because there were no current meter data to provide a velocity field or because immigration rates of pre-emergent larvae (NP) were unavailable. Of the remaining 34 estimates, 10 were derived from intervals where the difference between $\mathrm{NE}_{\mathrm{t}_{2}}$ and $\mathrm{N}_{\mathrm{t}_{2}}$ was $10 \%$ or less, suggesting near-zero mortality. However, we maintained the restriction that only mortality estimates in the 0 to $100 \%$ range could be rationally considered. As there was excellent agreement among the various measures of current speed and advection estimates, and as the error around estimates of post-emergent larvae were low relative to those around estimates of pre-emergent larvae, the remaining 24 negative mortalities are likely a function of imprecise immigration estimates.

The daily mortality $\left(\mathrm{M}_{5}\right)$ derived from the 40 positive estimates were extremely variable in 1982 and 1983 (Table 3). The estimates averaged $54.9 \%$ in 1982 and $65.3 \%$ in 1983, and were very similar to the 52.9 and $62.9 \% \mathrm{M}_{1}$ estimates for the same years (Table 2 ). The grand average daily mortality estimates (1982 and 1983 combined) reflected the influence of the various simplifying assumptions. The highest average estimate was for $\mathrm{M}_{2}(69.9 \%, \mathrm{n}=64)$ because only immigration was taken into account. The lowest average was for $M_{3}$ $(54.2 \%, \mathrm{n}=14)$ because only advective loss taken into account. The grand averages of $M_{4}$ and $M_{5}$, which included measures of immigration and emigration, were intermediate between the 2 extremes $\left(M_{4}=\right.$ $57.8 \%, n=23 ; M_{5}=60.1 \%, n=40$ ). The fewer $M_{4}$ estimates relative to $M_{5}$ reflect the limitations imposed by assuming that immigration was instantaneous and homogeneous, and that emigration was directly proportional to advective loss. The relative values of the various mortality estimates place some confidence in the $M_{5}$ average estimate of $60 \%$. If the $M_{2}$ and $M_{4}$ estimates, which were known to be biased, are accepted, the range of average daily mortality is 27 to $74 \%$ (Table 2 ). However, the average $M_{1}$ estimate was very similar to the average $M_{5}$ estimate. We suggest that at the sampling scale employed, immigration of pre-emergent larvae from the beach was effectively balanced by emigration of post-emergent larvae out of the cove.

The $\mathrm{M}_{5}$ values represent the best estimates of daily mortality. The degree of correlation among the other estimates provides an assessment of their relative efficiency. Both $\mathrm{M}_{2}$ and $\mathrm{M}_{4}$ were strongly correlated with $\mathrm{M}_{5}$, while $M_{1}$ and $M_{3}$ explained only 31 and $2 \%$ of the variation in $M_{5}$ respectively (Table 4). There were 40 paired estimates of $M_{2}$ and $M_{5}$ and they were highly correlated. There were only 9 paired estimates of $\mathrm{M}_{3}$ and $\mathrm{M}_{5}$ and they were poorly correlated. The coefficient of determination between $M_{2}$ and $M_{5}(0.66)$ was twice that between $M_{1}$ and $M_{5}(0.32)$, and we suggest that in Bryants Cove, accounting for larval immigration alone can explain between 32 and $66 \%$ of the observed mortality.

\section{DISCUSSION}

The results of our study demonstrated that the estimates of abundance and short-term mortality of post-emergent capelin rely heavily on sampling design, larval behaviour, immigration rates, and advection. We have previously shown that biases introduced into post-emergent population estimates by the sampling design employed, and by the vertical migratory behaviour of the larvae, can be addressed (Taggart \& Leggett 1984, 1987b). The major bias affecting the population size estimates and subsequent mortality estimates reported here was that imposed by the immigration rate of pre-emergent larvae. The considerable influence of immigration on sequential abundance estimates used in calculating mortality is not unique to our study. Other researchers have been unable to calculate mortality because the immigration of new larvae in to their censused population could not be taken into account (e.g. Munk et al. 1986). The confidence intervals around our estimates of pre-emergent larvae were large, and their influence was readily apparent in the nature of the correlation matrix of the various mortality 
Table 3. Daily $\left(\mathrm{M}_{5}\right)$ and instantaneous $\left(\mathrm{z}_{5}\right)$ mortality estimates and date and length of survey interval for the estimates

\begin{tabular}{|c|c|c|c|c|c|c|}
\hline Year & $\begin{array}{c}\text { Ending d } \\
\text { Month }\end{array}$ & $\begin{array}{l}\text { mpling } \\
\text { Day }\end{array}$ & Hour & $\begin{array}{c}\text { Interval } \\
\text { (h) }\end{array}$ & $\begin{array}{l}\% \text { Daily } \\
\text { mortality }\end{array}$ & $\begin{array}{c}\text { Instantaneous } \\
\text { mortality }\end{array}$ \\
\hline 82 & 7 & 2 & 20 & 26 & 2.67 & 0.0271 \\
\hline 82 & 7 & 7 & 18 & 24 & 14.86 & 0.1609 \\
\hline 82 & 7 & 12 & 18 & 25 & 90.83 & 2.3897 \\
\hline 82 & 7 & 14 & 16 & 46 & 52.30 & 0.7403 \\
\hline 82 & 7 & 16 & 16 & 10 & 8.50 & 0.0889 \\
\hline 82 & 7 & 17 & 5 & 6 & 92.84 & 2.6360 \\
\hline 82 & 7 & 18 & 6 & 25 & 61.96 & 0.9666 \\
\hline 82 & 7 & 19 & 1 & 13 & 98.39 & 4.1265 \\
\hline 82 & 7 & 19 & 13 & 12 & 97.21 & 3.5796 \\
\hline 82 & 7 & 20 & 19 & 30 & 63.10 & 0.9970 \\
\hline 82 & 7 & 23 & 15 & 29 & 68.57 & 1.1575 \\
\hline 82 & 7 & 28 & 10 & 39 & 8.21 & 0.0857 \\
\hline 83 & 7 & 2 & 16 & 22 & 96.94 & 3.4870 \\
\hline 83 & 7 & 3 & 12 & 6 & 99.46 & 5.2301 \\
\hline 83 & 7 & 3 & 18 & 6 & 87.90 & 2.1123 \\
\hline 83 & 7 & 4 & 13 & 19 & 70.60 & 1.2241 \\
\hline 83 & 7 & 4 & 18 & 5 & 95.28 & 3.0533 \\
\hline 83 & 7 & 6 & 11 & 41 & 48.72 & 0.6679 \\
\hline 83 & 7 & 7 & 18 & 31 & 56.69 & 0.8369 \\
\hline 83 & 7 & 8 & 17 & 23 & 70.11 & 1.2078 \\
\hline 83 & 7 & 9 & 11 & 18 & 29.26 & 0.3462 \\
\hline 83 & 7 & 9 & 17 & 6 & 94.85 & 2.9668 \\
\hline 83 & 7 & 10 & 16 & 6 & 25.77 & 0.2981 \\
\hline 83 & 7 & 11 & 22 & 9 & 55.79 & 0.8163 \\
\hline 83 & 7 & 12 & 3 & 5 & 35.03 & 0.4313 \\
\hline 83 & 7 & 12 & 10 & 7 & 41.05 & 0.5285 \\
\hline 83 & 7 & 12 & 17 & 7 & 91.91 & 2.5140 \\
\hline 83 & 7 & 13 & 5 & 6 & 20.00 & 0.2232 \\
\hline 83 & 7 & 13 & 11 & 6 & 92.27 & 2.5598 \\
\hline 83 & 7 & 13 & 18 & 7 & 73.80 & 1.3394 \\
\hline 83 & 7 & 14 & 14 & 6 & 96.99 & 3.5047 \\
\hline 83 & 7 & 15 & 16 & 7 & 97.25 & 3.5924 \\
\hline 83 & 7 & 17 & 19 & 8 & 52.45 & 0.7434 \\
\hline 83 & 7 & 18 & 3 & 8 & 99.97 & 8.2587 \\
\hline 83 & 7 & 19 & 16 & 37 & 11.34 & 0.1204 \\
\hline 83 & 7 & 20 & 18 & 26 & 38.98 & 0.4940 \\
\hline 83 & 7 & 24 & 17 & 29 & 88.08 & 2.1268 \\
\hline 83 & 7 & 26 & 12 & 26 & 25.45 & 0.2936 \\
\hline 83 & 7 & 27 & 15 & 27 & 56.19 & 0.8252 \\
\hline $\begin{array}{l}00 \\
83\end{array}$ & 7 & 30 & 15 & 26 & 76.44 & 1.4456 \\
\hline
\end{tabular}

Table 4. Pearson correlation between various daily mortality estimates $\left(M_{1}\right.$ to $\left.M_{5}\right)$ from the combined 1982 and 1983 data. Sample sizes are in parentheses and significant correlations $(\mathrm{p}<0.05)$ are underlined

\begin{tabular}{|c|c|c|c|c|}
\hline & $M_{1}$ & $\mathrm{M}_{2}$ & $\mathrm{M}_{3}$ & $M_{A}$ \\
\hline $\mathrm{M}_{2}$ & $0.68 \quad(46)$ & & & \\
\hline $\mathrm{M}_{3}$ & 0.67 (14) & $0.49(14)$ & & \\
\hline $\mathrm{M}_{4}$ & $0.75 \quad(22)$ & $\underline{0.69}(23)$ & $\underline{0.85}$ (14) & \\
\hline $\mathrm{M}_{5}$ & $0.56 \quad(30)$ & $\underline{0.81}(40)$ & $0.15(9)$ & $\underline{0.75}(16)$ \\
\hline
\end{tabular}

estimators ( $M_{1}$ to $M_{5}$; Table 4). The overdispersed nature of the pre-emergent population was responsible for the broad confidence limits. McGurk (1986) has also identified the biasing potential of patchy (over-dispersed) distributions of eggs and larvae on mortality estimates. The absence of more than one spawning cohort in 1982 and the accumulation of hatched larvae in the beach sediments between emergence events had the potential for inducing a large influence on emergence estimates. However, the strong statistical fit between the cumulative rate of larval increase in the sediments and the time since median spawning (Fig. 2) illustrated that this effect was small.

The effects of diffusion on the population estimates in our study were small because the water mass dynamics were dominated by advective processes. Although there was considerable upstream (landward) diffusion 
with respect to the advective trajectory, its effect on abundance estimates was negligible because diffusion processes were confined to the sampling area. Similar studies conducted at equivalent and larger scales also found that horizontal diffusion was inconsequential relative to advection (Talbot 1977, 1978, Gagnon \& Lacroix 1981, Fortier \& Leggett 1982).

Improvements in defining the velocity field and in calculating transport could possibly have been made by increasing the number of interpolation points and solving for continuity by more elaborate and expensive numerical models (Lam et al. 1984). However, we chose our approach because: (1) more elaborate techniques would not reflect the actual flow field any more precisely, given the limited number of observation points; (2) the velocity field was scaled to match the sampling grid; and (3) the multiple box model was computationally inexpensive. Nevertheless, the effect of advection on estimates of mortality was sizable. Not surprisingly the failure to account for advective losses resulted in elevated mortality. We believe the advective loss estimates were accurate because of long-term consistency in the average circulation and the absence of vertical shear (Taggart \& Leggett 1987b), the agreement between advection rates determined from current meters and from the dye experiments, and the consistency in the velocity field. The average rate of larval drift we observed $\left(5.2 \mathrm{~km} \mathrm{~d}^{-1}\right)$ is, however, greater than the 3.4 to $4.4 \mathrm{~km} \mathrm{~d}^{-1}$ average drift rate of larval herring Clupea harengus in the North Sea (Munk et al. 1986) and the 2.5 to $3.0 \mathrm{~km} \mathrm{~d}^{-1}$ average drift rate of postemergent capelin larvae in the St. Lawrence River (Fortier \& Leggett 1985).

The average daily mortality of $60 \%$ determined in this study was higher than most estimates reported for marine yolk-sac and post yolk-sac larvae isee Dahlberg 1979). The average, is however, consistent with those estimates reported from other recent studies which, like ours, were specifically designed to measure shortterm mortality during early larval drift. The short-term mortality of larval capelin at the time of yolk-sac absorption was $56 \% \mathrm{~d}^{-1}$ (Fortier \& Leggett 1985), and the daily mortality of jack mackerel Trachurus symmetricus was $80 \% \mathrm{~d}^{-1}$ just prior to yolk-sac absorption (Hewitt et al. 1985)

The wide variation in short-term mortality estimates evident in this study and the pronounced influence of immigration and advection on mortality estimates indicate the inappropriate nature of the several frequently employed assumptions concerned with: (1) constant larval production or immigration rates; (2) constant or inconsequential emigration rates; and (3) the spatial and temporal distribution of the target population. Failure to consider these constraints will lead to heavily biased mortality rates.
In assessing the 40 multiple mortality estimates of larval capelin, and by accounting for immigration and emigration of individuals into and out of the target populations, we have demonstrated that biases due to immigration and emigration, sampling, and the effects of behaviour and physical processes are important, and can be minimized. However, even provided with the many advantages that are relatively unique in the early life history of capelin and using the advantages of a small and well-defined system such as Bryants Cove, the task was far from trivial. The task of obtaining similarly unbiased estimates of larval mortality in other marine species that are more widely dispersed and tend to broadcast their eggs during more protracted spawning periods in larger and more open ocean systems must be considered formidable, particularly when using conventional sampling methods.

Acknowledgements. This study was supported by grants to W. C. L. from the Natural Sciences and Engineering Research Council of Canada (NSERC) and the Canada Department of Fisheries and Oceans (DFO). C.T.T was supported by an NSERC post-graduate scholarship, by the McConnell Foundation (McGill), and by Group interuniversitaire de recherche océanographiques du Québec (GIROQ). We are grateful to J. Carscadden and DFO, St. John's, Nfld., J.-Y Anctil and GIROQ, and R. Trites (Bedford Inst. Oceanography) for logistic support. N. Chalouhi, K. Tallon, J. C. Deguise, G. Maillet, M. Dolan, C. Gravel, G. Kerhuel, K. T Frank, K. W. Frank, F. Juanez, and D. Webb provided support in the field and lab. We also thank K. T. Frank and $Y$ deLafontaine for their comments, criticisms and advice during the design, execution and analysis of the work, and G. C. Harding and 3 anonymous reviewers who provided valuable criticisms and suggestions We are grateful to the residents of Bryants Cove who gave us invaluable assistance on many occasions.

\section{LITERATURE CITED}

Bailey, K. M. (1981). Larval transport and recruiment of pacific hake Merlucius productus. Mar Ecol. Prog. Ser. 6: 1-9

Carter, H. H. (1974). The measurement of rhodamine tracers in natural systems by fluorescence. Rapp. P.-v. Réun. Cons. int. Explor. Mer 167 193-200

Cushing, D. H. (1972). The production cycle and the numbers of marine fish. Symp. Zool. Soc. London 29: 213-232

Cushing, D. H. (1975), Marine ecology and fisheries. Cambridge Univ. Press, London

Cushing, D. H. (1986). The migration of larval and juvenile fish from spawning ground to nursery ground. J. Cons. int. Explor. Mer 43: 43-49

Dahiberg, M. D. (1979). A review of survival rates of fish eggs and larvae in relation to impact assessments. Mar. Fish. Rev. 41: 1-12

Fortier, L.. Leggett, W. C. (1982). Fickian transport and dispersal of larvae in estuaries. Can. J. Fish. Aquat. Sci. 39: $1150-1163$

Fortier, L., Leggett, W. C. (1985). A drift study of larval fish survival. Mar Ecol. Prog. Ser, 25: 245-257

Frank, K. T (1988). Independent distributions of fish larvae and their prey: natural paradox or sampling artifact? Can. J. Fish. Aquat. Sci. (in press) 
Frank, K. T., Leggett, W. C. (1981a). Wind regulation of emergence times and early larval survival in capelin (Mallotus villosus). Can. J. Fish. Aquat. Sci. 38: 215-223

Frank, K. T., Leggett, W. C. (1981b). Prediction of egg development and mortality rates in capelin (Mallotus villosus) from meteorological, hydrographic, and biological factors. Can. J. Fish. Aquat. Sci. 38: 1327-1338

Frank, K. T., Leggett, W. C. (1982). Coastal water mass replacement: its effect on zooplankton dynamics and the predatorprey complex associated with larval capelin (Mallotus villosus). Can. J. Fish. Aquat. Sci. 39: 991-1003

Gagnon, M., Lacroix, G. (1981). Zooplankton sample variability in a tidal estuary: an interperative model. Limnol. Oceanogr 26: 401-413

Hewitt, R. P., Theilacker, G. H., Lo, N. C. H. (1985). Causes of mortality in young jack mackerel. Mar. Ecol. Prog. Ser. 26: $1-10$

Hjort, J. (1914). Fluctuations in the great fisheries of northern Europe viewed in the light of biological research. Rapp. P.-v. Réun. Cons. int. Explor Mer 20: 1-228

Hjort, J. (1926). Fluctuations in the year classes of important food fishes. J. Cons. int. Explor. Mer 1: 5-38

Jones, R. (1973). Density-dependent regulation of cod and haddock. Rapp. P.-v. Réun. Cons. int. Explor Mer 164: $156-173$

Lam, D. C. L., Murthy, C. R., Simpson, R. B. (1984). Effluent transport and diffusion models for the coastal zone. Springer-Verlag, New York

Lasker, R. (1975). Field criteria for the survival of anchovy larvae: the relation between inshore chlorophyll maximum layers and successful first feeding. Fish. Bull. U.S. 73 : $453-462$

Leggett, W. C., Frank, K. T., Carscadden, J. E. (1984). Meteorological and hydrographic regulation of year-class strength in capelin (Mallotus villosus). Can. J. Fish. Aquat. Sci. 41 1193-1201

McGurk, M. D. (1986). Natural mortality of marine pelagic fish eggs and larvae: role of spatial patchiness. Mar. Ecol. Prog. Ser, 34: 227-242

Munk, P., Christensen, V., Paulsen, H. (1986). Studies of a larval herring (Clupea harengus L.) patch in the Buchan area. II. Growth, mortality, and drift of larvae. Dana 6: 11-24

Nelson, W., Ingham, M. C., Schaff, W. E. (1977). Larval transport and year-class strength of Atlantic menhaden, Brevoortia tyrannus. Fish. Bull. U. S. 75: 23-42
Okubo, A. (1980). Diffusion and ecological problems: mathematical models. Springer-Verlag, New York

Pearcy, W. G. (1962). Ecology of an estuarine population of winter flounder, Pseudopleuronectese americanus (Walbum). II. Distribution and dynamics of larvae. Bull. Bingham. oceanogr. Coll 18: 16-38

Peterman, R. M., Bradford, M. ․ (1987). Wind speed and mortality rate of a marine f:sh, the northern anchovy (Engraulis mordax). Science 235: 354-356

Rothschild, B. J. (1986). Dynamics of marine fish populations. Harvard Univ. Press, Cambridge, Massachusetts

Sinclair, M., Tremblay, M. J., Bernal, P. (1985). El Nino events and variability in Pacific mackerel (Scomber scombrus) survival index: support for Hjort's second hypothesis. Can. J. Fish. Aquat. Sci. 42: 602-608

Taggart, C. T., Leggett, W. C. (1984). Efficiency of largevolume plankton pumps, and evaluation of a design suitable for deployment from small boats. Can. J. Fish. Aquat. Sci. 41: 1428-1435

Taggart, C. T., Leggett, W. C. (1987a). Short-term mortality in post-emergent larval capelin Mallotus villosus. II. Importance of food and predator density, and density-dependence. Mar. Ecol. Prog. Ser. 41: 219-229

Taggart, C. T., Leggett, W. C. (1987b). Wind-forced hydrodynamics and their interaction with larval fish and plankton abundance: a time-series analysis of physical-biological data. Can. J. Fish. Aquat. Sci. 44: 438-451

Talbot, J. W. (1977). The dispersal of plaice eggs and larvae in the Southern Bight of the North Sea. J. Cons. int. Explor Mer 37: 221-248

Talbot, J. W. (1978). Changes in plaice larval dispersal in the last fifteen years. Rapp. P.-v Réun. Cons. int. Explor. Mer 172: $114-123$

Tilseth, S., Ellertsen, B. (1984). The detection and distribution of larval Arcto-Norwegian cod, Gadus morhua, food organisms by an in situ particle counter. Fish. Bull. U. S. 82: $141-156$

Ware, D. M. (1975). Relation between egg size, growth, and natural mortality of larval fish. J. Fish. Res. Bd Can. 32: 2503-2512

Weidemann, H. (ed.) (1973). The ICES diffusion experiment. RHENO 1965. Rapp. P.-v. Réan. Cons. int. Explor. Mer 163: $1-11$

This article was presented by Dr G. C. Harding; it was accepted for printing on September 15, 1987 